Jurnal Indonesia Sosial Teknologi:p-ISSN: 2723 - 6609

e-ISSN :2745-5254

Vol. 2, No.12 Desember 2021

\title{
PENGARUH PARAMETER PROSES TERHADAP KEKUATAN TARIK PRODUK 3D PRINTING MENGGUNAKAN FILAMEN POLYLACTIC ACID (PLA) BUATAN R3D MAKER
}

\author{
Rikky Ardiansyah ${ }^{1}$, Zaldy Sirwansyah Suzen ${ }^{2}$, Erwansyah $^{3}$ \\ Jurusan Teknik Mesin, Politeknik Manufaktur Negeri Bangka Belitung ${ }^{1,2,3}$ \\ Email: rikkyardiansyah12@gmail.com¹, syahdika99@gmail.com², \\ erwansyah.polmanbabel@gmai.com ${ }^{3}$.
}

\begin{abstract}
Abstrak
Saat ini teknologi di dunia industri manufaktur telah mengalami kemajuan yang sangat pesat salah satunya adalah 3D printing. 3D printing merupakan salah satu teknologi yang mengubah data digital menjadi objek 3D dengan menggunakan proses Additive manufacturing pada saat memproduksi suatu produk. Penelitian ini dilakukan untuk mengetahui pengaruh infill pattern dan nozzle temperature terhadap kekuatan tarik produk 3D printing dengan orientasi sudut pencetakan vertikal sebesar $90^{\circ}$ mengggunakan filamen polylactic acid (PLA). Pada penelitian material polylactic acid (PLA) akan dicetak sesuai dengan standar uji tarik ASTM D638-14 Type 4. Variasi parameter proses yang digunakan pada infill pattern berupa lines, cubic, cubic division, quarter cubic, grid, octet, concentric, zig zag, tri hexagon, triangles, gyroid, cross dan cross $3 \mathrm{D}$ dan nilai dari nozzle temperature yang digunakan sebesar $205^{\circ} \mathrm{C}, 215^{\circ} \mathrm{C}$, dan $225^{\circ} \mathrm{C}$. Pada penelitian menunjukan bahwa bahwa infill pattern dan nozzle temperature memiliki pengaruh terhadap kekuatan tarik produk 3D printing dengan orientasi sudut pencetakan vertikal sebesar $0^{\circ}$ menggunakan filamen polylactic acid (PLA) Nilai kekuatan tarik tertinggi yang terdapat pada penelitian ini sebesar $42,5 \mathrm{MPa}$ yang menggunakan infill pattern dengan tipe zig zag dan nozzle temperature sebesar $205^{\circ} \mathrm{C}$. Sedangkan nilai kekuatan tarik terendah sebesar $30 \mathrm{MPa}$ yang menggunakan infill pattern dengan tipe cross
\end{abstract}

Kata kunci: $3 D$ printer; infill pattern; nozzle temperature; orientasi pencetakan

\section{Abstract}

Currently, technology in the manufacturing industry has progressed very rapidly, one of which is $3 D$ printing. $3 D$ printing is a technology that converts digital data into $3 D$ objects using the Additive manufacturing process when producing a product. This research was conducted to determine the effect of infill pattern and nozzle temperature on the tensile strength of $3 D$ printing products with a vertical printing angle orientation of $0^{\circ}$ using polylactic acid (PLA) filaments. In the research, polylactic acid (PLA) material will be printed according to the ASTM D638-14 Type 4 tensile test standard. Variations of process parameters used in the infill pattern are lines, cubic, cubic division, quarter cubic, grid, octet, concentric, zig zag, tri hexagons, triangles, gyroids, cross and cross $3 D$ and the values of the nozzle temperatures used are $205^{\circ} \mathrm{C}, 215^{\circ} \mathrm{C}$, and $225^{\circ} \mathrm{C}$. The research shows that the infill 
Rikky Ardiansyah, Zaldy Sirwansyah Suzen, Erwansyah

pattern and nozzle temperature have an influence on the tensile strength of $3 D$ printing products with a vertical printing angle orientation of $0^{\circ}$ using polylactic acid(PLA) filament. The highest tensile strength value found in this study was 42.5 $M P a$ using the infill pattern. with a zig zag type and a nozzle temperature of $205^{\circ} \mathrm{C}$. Whilethe lowest tensile strength value is $30 \mathrm{MPa}$ using an infill pattern with a cross type

Keywords: 3D printers; infill pattern; nozzle temperature; printing orientation

\section{Pendahuluan}

Perkembangan teknologi di dunia industri manufaktur akan menyebabkan terciptanya suatu persaingan yang ketat terutama untuk memperoleh suatu proses produksi yang dapat menghasilkan produk dengan keakuratan dan ketepatan dimensi yang tinggi, sehingga akan menyebabkan peningkatan kualitas dari produk yang dibuat. Selama ini proses produksi yang digunakan untuk membuat prototype dari suatu produk di industri manufaktur masih menggunakan metode untuk menghilangkan sebagian material dengan menggunakan mesin-mesin perkakas sehingga akan menyebabkan adanya material yang terbuang yang biasanya dikenal sebagai subtractive manufacturing. Oleh karena itu, industri manufaktur mulai mengembangkan suatu proses produksi yang tidak membuang atau menghilangkan sebagian material dalam proses produksi akan tetapi proses yang digunakan adalah dengan menggunakan metode penambahan material yang dikenal dengan proses Additive Manufacture (AM) (Arif, 2016).

Additive Manufcturing memiliki beberapa sistem yang sering digunakan di bidang industri seperti selective laser sintering (SLS), inkjet modeling (IJM), stereo-lithography (SLA), dirrect metal deposition (DMD), dan fussed deposition modelling (FDM) (Mohamed, Masood, \& Bhowmik, 2015). Pencetakan tiga dimensi yang menggunakan fussed deposition modelling (FDM) akan menyebabkan biaya produksi menjadi lebih kecil dan mempercepat proses pembuatan produk (Riza, Budiyantoro, \& Nugroho, 2020). additive manufacturing memiliki beberapa jenis teknologi salah satunya adalah 3D Printing. Dimana pada 3D printing material akan disusun secara layer by layer yang telah di kontrol menggunakan komputer sehingga dapat menghasilkan struktur tiga dimensi (3D) (Izdebska-Podsiadły \& Thomas, 2015).

Dalam 3D printing terdapat menggunakan bahan berbentuk filamen yang berfungsi sebagai bahan pengisi bentuk. Terdapat beberapa bahan filamen yang sering digunakan seperti polyethylene terephthalate glycol (PETG), nylon, acrylonitrile styrene acrylate (ASA), acrylonitrile butadiene styrene (ABS), polylactic acid (PLA) dan lainlain. PLA merupakan salah satu jenis termoplastik yang memiliki banyak keunggulan. Keunggulan yang dimiliki oleh PLA adalah memiliki harga yang murah, memiliki kekuatan dan kemudahan dalam pencetakan, dan memiliki faktor penyusutan yang rendah sehingga produk tidak akan mengalami perubahan bentuk atau bengkok pada saat proses pendinginan yang kuat. Dalam pembuatan produk 3D printing suhu yang digunakan dalam pencetakan menggunakan filamen PLA sebesar $180^{\circ} \mathrm{C}-210^{\circ} \mathrm{C}$. (Grabowik, Kalinowski, Ćwikła, Paprocka, \& Kogut, 2017). 
Menurut (Sulistiyanto, 2017) Adapun beberapa penelitian yang membahas tentang optimalisasi dan pengaruh parameter proses 3D printing untuk menghasilkan produk dengan kekuatan tarik yang optimal telah banyak dilakukan. (Nugroho \& Budiantoro, 2019) melakukan penelitian untuk mengetahui pengaruh parameter proses optimal terhadap sifat mekanik dari produk hasil pencetakan 3D Printing yang menggunakan filamen PLA. Parameter proses yang diujikan pada penelitian ini memiliki 3 level variasi, dengan parameter proses yang digunakan sepertti: infill pattern, infill density, extrusion width dan nozzle temperature. Dari penelitian ini didapatkan hasil bahwa kekuatan tarik dari produk 3D printing dipengaruhi oleh Infill density yang di ikuti oleh nozzle temperature, infill pattern, dan extrusion width dengan kekuatan tarik optimum sebesar 30,52 Mpa dengan interval kepercayaan sebesar 95\% yang terdapat pada produk dengan nilai Infill density sebesar $75 \%$, nozzle temperature sebesar $215^{\circ} \mathrm{C}$, Infill pattern honey comb, dan extrusion width sebesar 0,3mm.

Penelitian yang dilakukan oleh (Suzen, 2020) yang bertujuan untuk mengetahui apakah kekuatan dari tarik produk 3D printing yang menggunakan filamen PLA+ ESUN dipengaruhi oleh parameter proses seperti infill pattern dan nozzle temperature. Pada penelitian ini parameter yang digunakan seperti: 13 tipe infill pattern dengan variasi level yang digunakan pada Infill pattern yaitu lines, cubic, cubic division, quarter cubic, grid, octet, concentric, zig zag, tri hexagon, triangles, gyroid, cross dan cross 3D, nozzle temperature dengan 3 variasi suhu sebesar $225^{\circ} \mathrm{C}, 215^{\circ} \mathrm{C}$ dan $205^{\circ} \mathrm{C}$, bed temperature dengan suhu $60{ }^{\circ} \mathrm{C}$, layer thickness dengan ketebalan sebesar $0,2 \mathrm{~mm}$, travel speed dengan kecepatan sebesar $100 \mathrm{~mm} / \mathrm{s}$, printing speed dengan kecepatan sebesar $50 \mathrm{~mm} / \mathrm{s}$ sehingga menghasilkan 39 spesimen uji. Dari penelitian ini didapatkan hasil bahwa kekuatan tarik material ESUN PLA+ dipengaruhi oleh infill pattern dan nozzle temperature dengan nilai kekuatan tarik tertinggi yang menggunakan infill pattern dengn tipe concentric dengan suhu yang digunakan pada nozzle sebesar $215^{\circ} \mathrm{C}$ dengan nilai kekuata tarik sebesar 43,20 MPa dan nilai kekuatan tarik terendah sebesar 24,50 yang menggunakan inffil patern dengan variasi cross dan suhu nozzle yang digunakan sebesar $205^{\circ} \mathrm{C}$.

(Yao, Deng, Zhang, \& Li, 2019) telah melakukan penelitian untuk mengetahui pengaruh parameter kekuatan tarik sehingga mendapatkan hasil yang optimal pada produk 3d printing yang menggunakan filamen PLA. Parameter yang digunakan pada penelitian ini adalah sudut pencetakan dan Layer thickness dimana sudut yang digunakan yaitu $0^{\circ}, 15^{\circ}, 30^{\circ}, 45^{\circ}, 75^{\circ}$, dan $90^{\circ}$ dengan variasi 3 level pada layer thickness. Dari penelitian ini peneliti menarik kesimpulan bahwa kekuatan tarik produk 3D printing mengalami perubahan yang signifikan dimana nilai GAP terbesar berada diantar sudut $0^{\circ}$ - 90 dengan Layer thickness sebesar 0,1 mm. Nilai gap yang terdapat pada sudut $0^{\circ}-$ $90^{\circ}$ dengan Layer thickness sebesar 0,1 mm adalah 52,29\%.

Berdasarkan penelitian sebelumnya dapat diketahui pada saat proses pengerjaan produk 3D dengan menggunakan mesin 3D printer parameter proses seperti Infill density, nozzle temperature, infill pattern, extrusion width dan orientasi pencetakan dapat mempengaruhi kekuatan tarik produk 3D printing (Budiman, Anggono, \& Tanoto, 2016). 
Oleh sebab itu penelitian ini dilakukan untuk mengetahui pengaruh infill pattern, dan nozzle temperature terhadap kekuatan tarik produk 3D printing dengan orientasi sudut pencetakan vertikal sebesar $90^{\circ}$ mengggunakan filamen polylactic acid (PLA) dan diharapkan hasil dari penelitian ini dapat digunakan untuk produk industri manufaktur.

\section{Metode Penelitian}

\section{Alat dan Bahan}

Spesimen akan di cetak menggunakan mesin 3D printer merek Anet Et4 dengan printing Area X, Y, dan Z sebesar $220 \mathrm{~mm}$ x $220 \mathrm{~mm}$ x $250 \mathrm{~mm}$ dan menggunakan nozzle berukuran 0,4 mm dengan material yang digunakan berupa fillamen PLA buatan R3D MAKER dengan diameter $1,75 \mathrm{~mm}$. Pengujian tarik pada penelitian ini menggunakan mesin uji tarik merek Zwick Roell Z020 type Xforce K.

\section{Metode yang digunakan}

Metode yang digunkan pada penelitian ini adalah metode eksperimen faktorial dimana pada penelitian ini infill pattern dan nozzle temperature merupakan paramater proses yang diujikan dengan jumlah varians level secara berurutan sebanyak 13 dan 3 . Untuk mencari banyaknya kombinasi parameter maka dapat dilakukan perkalian varians level antar parameter sehingga didapatkanlah 39 kombinasi parameter yang dapat dilihat pada tabel 1.

Tabel 1 Kombinasi Parameter

\begin{tabular}{|c|c|c|c|c|c|c|c|c|}
\hline $\begin{array}{l}\operatorname{Exp} \\
. N o\end{array}$ & $\begin{array}{c}\text { Nozzle } \\
\text { Tempera } \\
\text { ture }\left({ }^{\circ} \mathrm{C}\right)\end{array}$ & $\begin{array}{c}\text { Layer } \\
\text { thickne } \\
\text { ss } \\
(\mathrm{mm})\end{array}$ & $\begin{array}{c}\text { Bed } \\
\text { temperat } \\
\text { ure }\left({ }^{\circ} \mathrm{C}\right)\end{array}$ & $\begin{array}{l}\text { Travel } \\
\text { Speed } \\
(\mathrm{mm} / \mathrm{s})\end{array}$ & $\begin{array}{c}\text { Printin } \\
g \\
\text { Speed } \\
(\mathrm{mm} / \mathrm{s})\end{array}$ & $\begin{array}{c}\text { Orientasi } \\
\text { vertikal } \\
\left(^{\circ}\right)\end{array}$ & $\begin{array}{c}\text { Infill } \\
\text { densit } \\
y(\%)\end{array}$ & $\begin{array}{c}\text { Infill } \\
\text { patern }\end{array}$ \\
\hline 1 & 205 & 0.2 & 60 & 100 & 40 & 90 & 80 & Triangles \\
\hline 2 & 205 & 0.2 & 60 & 100 & 40 & 90 & 80 & Lines \\
\hline 3 & 205 & 0.2 & 60 & 100 & 40 & 90 & 80 & Grid \\
\hline 4 & 205 & 0.2 & 60 & 100 & 40 & 90 & 80 & $\begin{array}{c}\text { Tri } \\
\text { Hexagon }\end{array}$ \\
\hline 5 & 205 & 0.2 & 60 & 100 & 40 & 90 & 80 & Cubic \\
\hline 6 & 205 & 0.2 & 60 & 100 & 40 & 90 & 80 & $\begin{array}{c}\text { Cubic } \\
\text { Subdivisio } \\
\mathrm{n}\end{array}$ \\
\hline 7 & 205 & 0.2 & 60 & 100 & 40 & 90 & 80 & $\begin{array}{c}\text { Quarter } \\
\text { Cubic }\end{array}$ \\
\hline 8 & 205 & 0.2 & 60 & 100 & 40 & 90 & 80 & Concentric \\
\hline 9 & 205 & 0.2 & 60 & 100 & 40 & 90 & 80 & Octet \\
\hline 10 & 205 & 0.2 & 60 & 100 & 40 & 90 & 80 & Cross \\
\hline 11 & 205 & 0.2 & 60 & 100 & 40 & 90 & 80 & Cross 3D \\
\hline 12 & 205 & 0.2 & 60 & 100 & 40 & 90 & 80 & Gyroid \\
\hline
\end{tabular}


Pengaruh Parameter Proses Terhadap Kekuatan Tarik Produk 3d Printing Menggunakan Filamen Polylactic Acid (PLA) Buatan R3d Maker

\begin{tabular}{|c|c|c|c|c|c|c|c|c|}
\hline $\begin{array}{l}\operatorname{Exp} \\
. N o\end{array}$ & $\begin{array}{c}\text { Nozzle } \\
\text { Tempera } \\
\text { ture }\left({ }^{\circ} \mathrm{C}\right)\end{array}$ & $\begin{array}{c}\text { Layer } \\
\text { thickne } \\
\text { ss } \\
(\mathrm{mm})\end{array}$ & $\begin{array}{c}\text { Bed } \\
\text { temperat } \\
\text { ure }\left({ }^{\circ} \mathrm{C}\right)\end{array}$ & $\begin{array}{l}\text { Travel } \\
\text { Speed } \\
(\mathrm{mm} / \mathrm{s})\end{array}$ & $\begin{array}{c}\text { Printin } \\
g \\
\text { Speed } \\
(\mathrm{mm} / \mathrm{s})\end{array}$ & $\begin{array}{c}\text { Orientasi } \\
\text { vertikal } \\
\left(^{\circ}\right)\end{array}$ & $\begin{array}{c}\text { Infill } \\
\text { densit } \\
y(\%)\end{array}$ & $\begin{array}{c}\text { Infill } \\
\text { patern }\end{array}$ \\
\hline 13 & 205 & 0.2 & 60 & 100 & 40 & 90 & 80 & Zig Zag \\
\hline 14 & 215 & 0.2 & 60 & 100 & 40 & 90 & 80 & Triangles \\
\hline 15 & 215 & 0.2 & 60 & 100 & 40 & 90 & 80 & Lines \\
\hline 16 & 215 & 0.2 & 60 & 100 & 40 & 90 & 80 & Grid \\
\hline 17 & 215 & 0.2 & 60 & 100 & 40 & 90 & 80 & $\begin{array}{c}\text { Tri } \\
\text { Hexagon }\end{array}$ \\
\hline 18 & 215 & 0.2 & 60 & 100 & 40 & 90 & 80 & Cubic \\
\hline 19 & 215 & 0.2 & 60 & 100 & 40 & 90 & 80 & $\begin{array}{c}\text { Cubic } \\
\text { Subdivisio } \\
\mathrm{n}\end{array}$ \\
\hline 20 & 215 & 0.2 & 60 & 100 & 40 & 90 & 80 & $\begin{array}{c}\text { Quarter } \\
\text { Cubic }\end{array}$ \\
\hline 21 & 215 & 0.2 & 60 & 100 & 40 & 90 & 80 & Concentric \\
\hline 22 & 215 & 0.2 & 60 & 100 & 40 & 90 & 80 & Octet \\
\hline 23 & 215 & 0.2 & 60 & 100 & 40 & 90 & 80 & Cross \\
\hline 24 & 215 & 0.2 & 60 & 100 & 40 & 90 & 80 & Cross 3D \\
\hline 25 & 215 & 0.2 & 60 & 100 & 40 & 90 & 80 & Gyroid \\
\hline 26 & 215 & 0.2 & 60 & 100 & 40 & 90 & 80 & Zig Zag \\
\hline 27 & 225 & 0.2 & 60 & 100 & 40 & 90 & 80 & Triangles \\
\hline 28 & 225 & 0.2 & 60 & 100 & 40 & 90 & 80 & Lines \\
\hline 29 & 225 & 0.2 & 60 & 100 & 40 & 90 & 80 & Grid \\
\hline 40 & 225 & 0.2 & 60 & 100 & 40 & 90 & 80 & $\begin{array}{c}\text { Tri } \\
\text { Hexagon }\end{array}$ \\
\hline 31 & 225 & 0.2 & 60 & 100 & 40 & 90 & 80 & Cubic \\
\hline 32 & 225 & 0.2 & 60 & 100 & 40 & 90 & 80 & $\begin{array}{c}\text { Cubic } \\
\text { Subdivisio } \\
\mathrm{n}\end{array}$ \\
\hline 33 & 225 & 0.2 & 60 & 100 & 40 & 90 & 80 & $\begin{array}{l}\text { Quarter } \\
\text { Cubic }\end{array}$ \\
\hline 34 & 225 & 0.2 & 60 & 100 & 40 & 90 & 80 & Concentric \\
\hline 35 & 225 & 0.2 & 60 & 100 & 40 & 90 & 80 & Octet \\
\hline 36 & 225 & 0.2 & 60 & 100 & 40 & 90 & 80 & Cross \\
\hline 37 & 225 & 0.2 & 60 & 100 & 40 & 90 & 80 & Cross 3D \\
\hline 38 & 225 & 0.2 & 60 & 100 & 40 & 90 & 80 & Gyroid \\
\hline 39 & 225 & 0.2 & 60 & 100 & 40 & 90 & 80 & Zig Zag \\
\hline
\end{tabular}




\section{Proses Pengambilan data}

Semua proses pada penelitian ini di awali dengan studi Pustaka untuk menentukan parameter yang akan digunakan. selanjutnya spesimen uji akan di desain menggunakan software Fusion 360 Student Licence berdasarkan standar yang digunakan yaitu ASTM D638-14 Type 4 dan di simpan dalam format STL (*.stl). Setelah itu hasil desain spesimen uji di olah menggunakan software Ultimaker Cura 4.10.0 utuk dilakukan proses slicing berdsarkan parameter yang akan digunakan dan hasil slicing di simpan dalam bentuk $G$-code.

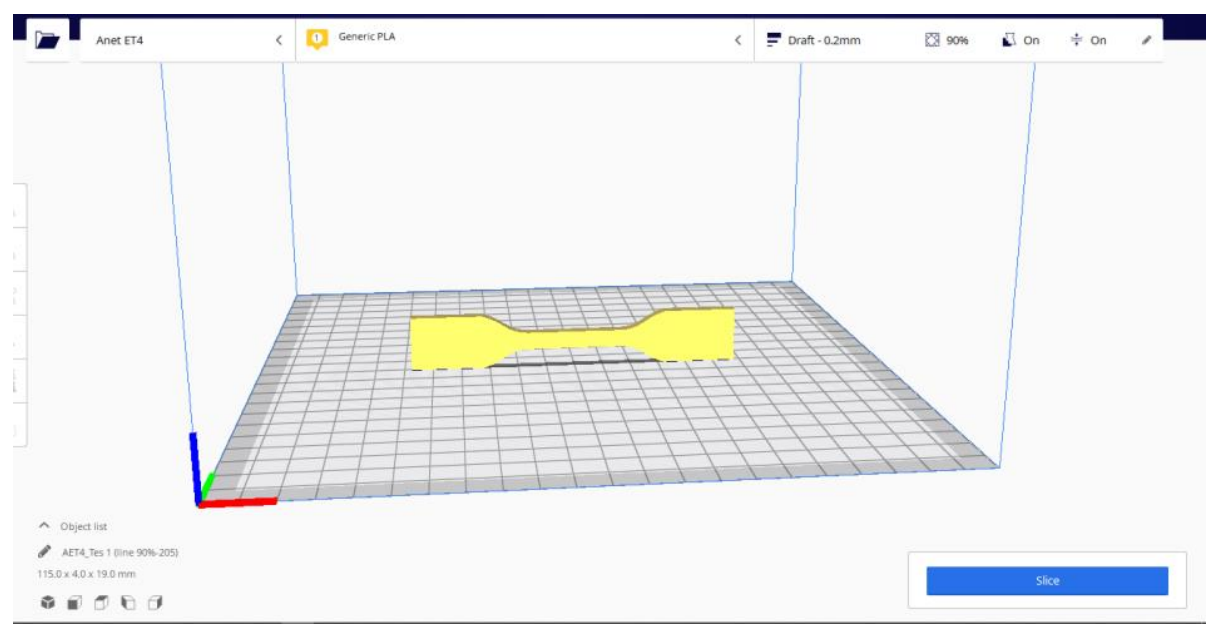

\section{Gambar 1 Proses Slicing}

Selanjutnya lakukaan persiapan pencetakan spesimen uji seperti: melakukan kalibrasi mesin 3D printer untuk menghasilkan permukaan yang datar pada bed, memindahkan G-Code dari pc ke dalam mesin 3D printer menggunakan MicroSD, memasang filamen ke dalam mesin, dan memanaskan nozzle dan bed. Setelah selesai melakukan persiapan maka langkah selanjutnya adalah mencetak spesimen uji hingga 39 spesimen.

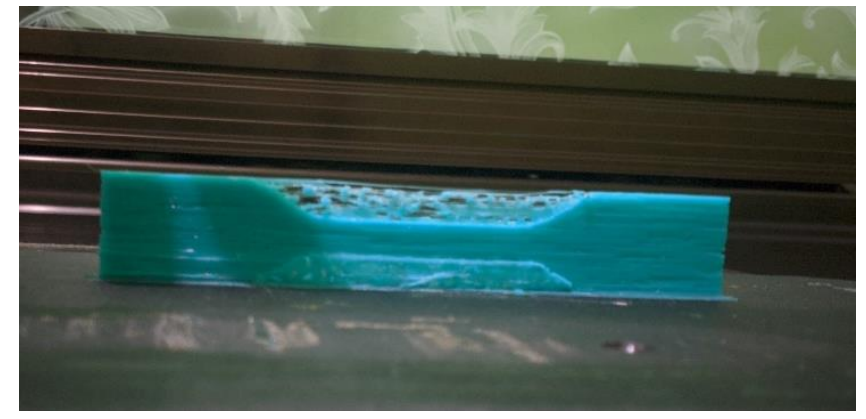

Gambar 2 Proses Pencetakan Spesimen Uji

Setelah semua spesimen uji tercetak dan telah di identifikasi maka selanjutnya melakukan pengujian tarik untuk mendapatkan nilai kekuatan tarik dari spesimen yang telah dicetak. Pengujian tarik pada penelitian ini menggunakan mesin uji tarik merek Zwick Roell Z020 type Xforce K. 


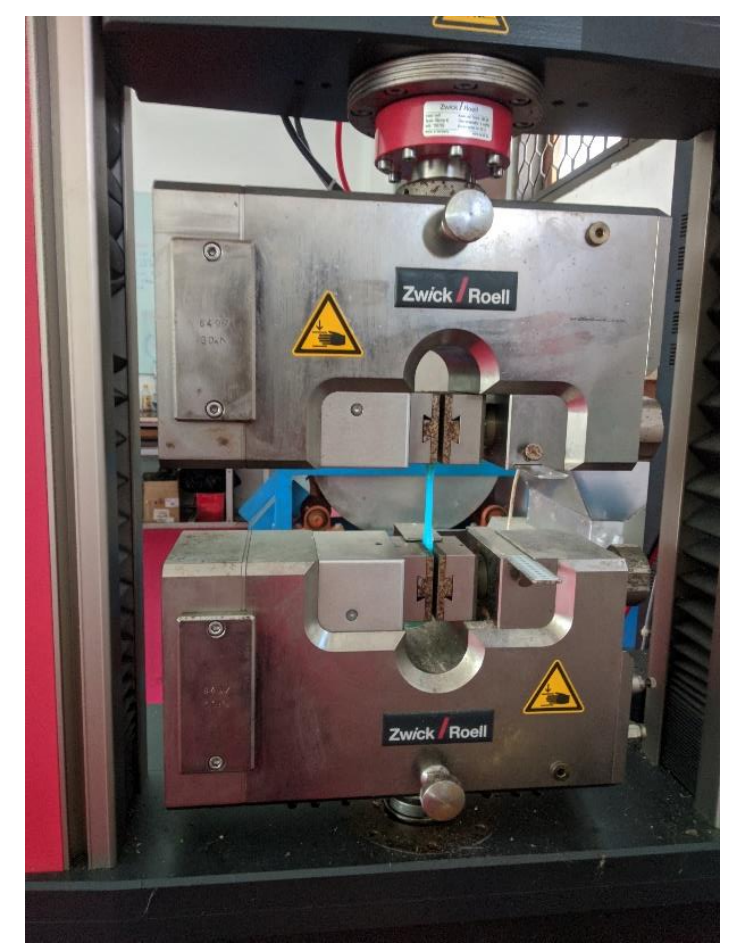

Gambar 3 Proses Pengujian Tarik

\section{Hasil dan Pembahasan}

\section{Hasil Pengujian Tarik}

Pada penelitian ini didapatkanlah hasil berupa hasil pengujian tarik dari spesimen yang dibuat menggunakan mesin 3D printing Anet Et4 menggunakan filamen polylactic acid (PLA) buatan R3D MAKER. Pengujian tarik dilakukan menggunakan mesin Universal Testing Machining merek Zwick Roell Z020 tipe Xforce K yang memiliki tujuan untuk mendapatkan nilai kekuatan tarik dari spesimen dengan standar yang digunakan berupa ASTM D638-14 tipe IV yang telah dicetak menggunakan mesin 3D printing. Hasil pengujian tarik ditunjukkan pada Tabel 2.

Tabel 2 Hasil Pengujian Tarik

\begin{tabular}{cccccccccc}
\hline $\begin{array}{c}\text { Exp. } \\
\text { No }\end{array}$ & $\begin{array}{c}\text { Nomper } \\
\text { Temper } \\
\text { ature } \\
\left({ }^{\circ} \boldsymbol{C}\right)\end{array}$ & $\begin{array}{c}\text { Layer } \\
\text { thickn } \\
\text { ess } \\
(\mathbf{m m})\end{array}$ & $\begin{array}{c}\text { Bemperatu } \\
\boldsymbol{r e}\left({ }^{\circ} \boldsymbol{C}\right)\end{array}$ & $\begin{array}{c}\text { Travel } \\
\text { Speed } \\
(\mathbf{m m} / \mathbf{s})\end{array}$ & $\begin{array}{c}\text { Printing } \\
\text { Speed } \\
(\mathbf{m m} / \mathbf{s})\end{array}$ & $\begin{array}{c}\text { Orientasi } \\
\text { vertikal } \\
\left({ }^{\circ}\right)\end{array}$ & $\begin{array}{c}\text { Infill } \\
\text { densi } \\
\text { ty } \\
(\%)\end{array}$ & $\begin{array}{c}\text { Infill } \\
\text { patern }\end{array}$ & $\begin{array}{c}\text { Kilai } \\
\text { Kekuatan } \\
\text { Tarik } \\
(\mathbf{M P a})\end{array}$ \\
\hline 1 & 205 & 0.2 & 60 & 100 & 40 & 90 & 80 & Triangles & 34,3 \\
\hline 2 & 205 & 0.2 & 60 & 100 & 40 & 90 & 80 & Lines & 41,7 \\
\hline 3 & 205 & 0.2 & 60 & 100 & 40 & 90 & 80 & Grid & 37,6 \\
\hline 5 & 205 & 0.2 & 60 & 100 & 40 & 90 & 80 & $\begin{array}{c}\text { Tri } \\
\text { Hexagon }\end{array}$ & 35,3 \\
\hline 6 & 205 & 0.2 & 60 & 100 & 40 & 90 & 80 & Cubic & 40,7 \\
\hline
\end{tabular}


Rikky Ardiansyah, Zaldy Sirwansyah Suzen, Erwansyah

\begin{tabular}{|c|c|c|c|c|c|c|c|c|c|}
\hline $\begin{array}{l}\text { Exp. } \\
\text { No }\end{array}$ & $\begin{array}{c}\text { Nozzle } \\
\text { Temper } \\
\text { ature } \\
\left({ }^{\circ} \mathrm{C}\right)\end{array}$ & $\begin{array}{c}\text { Layer } \\
\text { thickn } \\
\text { ess } \\
(\mathrm{mm})\end{array}$ & $\begin{array}{c}\text { Bed } \\
\text { temperatu } \\
\text { re }\left({ }^{\circ} \mathrm{C}\right)\end{array}$ & $\begin{array}{c}\text { Travel } \\
\text { Speed } \\
(\mathrm{mm} / \mathrm{s})\end{array}$ & $\begin{array}{c}\text { Printing } \\
\text { Speed } \\
(\mathrm{mm} / \mathrm{s})\end{array}$ & $\begin{array}{c}\text { Orientasi } \\
\text { vertikal } \\
\left(^{\circ}\right)\end{array}$ & $\begin{array}{c}\text { Infill } \\
\text { densi } \\
\text { ty } \\
(\%)\end{array}$ & $\begin{array}{c}\text { Infill } \\
\text { patern }\end{array}$ & $\begin{array}{c}\text { Nilai } \\
\text { Kekuatan } \\
\text { Tarik } \\
(\text { MPa })\end{array}$ \\
\hline 7 & 205 & 0.2 & 60 & 100 & 40 & 90 & 80 & $\begin{array}{c}\text { Quarter } \\
\text { Cubic }\end{array}$ & 41,1 \\
\hline 8 & 205 & 0.2 & 60 & 100 & 40 & 90 & 80 & $\begin{array}{c}\text { Concentri } \\
\text { c }\end{array}$ & 31,8 \\
\hline 9 & 205 & 0.2 & 60 & 100 & 40 & 90 & 80 & Octet & 38,4 \\
\hline 10 & 205 & 0.2 & 60 & 100 & 40 & 90 & 80 & Cross & 30 \\
\hline 11 & 205 & 0.2 & 60 & 100 & 40 & 90 & 80 & Cross 3D & 32,5 \\
\hline 12 & 205 & 0.2 & 60 & 100 & 40 & 90 & 80 & Gyroid & 39,8 \\
\hline 13 & 205 & 0.2 & 60 & 100 & 40 & 90 & 80 & Zig Zag & 42,3 \\
\hline 14 & 215 & 0.2 & 60 & 100 & 40 & 90 & 80 & Triangles & 32,1 \\
\hline 15 & 215 & 0.2 & 60 & 100 & 40 & 90 & 80 & Lines & 42,2 \\
\hline 16 & 215 & 0.2 & 60 & 100 & 40 & 90 & 80 & Grid & 36,5 \\
\hline 17 & 215 & 0.2 & 60 & 100 & 40 & 90 & 80 & $\begin{array}{c}\text { Tri } \\
\text { Hexagon }\end{array}$ & 34,1 \\
\hline 18 & 215 & 0.2 & 60 & 100 & 40 & 90 & 80 & Cubic & 40,1 \\
\hline 19 & 215 & 0.2 & 60 & 100 & 40 & 90 & 80 & $\begin{array}{c}\text { Cubic } \\
\text { Subdivisio } \\
\mathrm{n}\end{array}$ & 32,9 \\
\hline 20 & 215 & 0.2 & 60 & 100 & 40 & 90 & 80 & $\begin{array}{c}\text { Quarter } \\
\text { Cubic }\end{array}$ & 40,5 \\
\hline 21 & 215 & 0.2 & 60 & 100 & 40 & 90 & 80 & $\begin{array}{c}\text { Concentri } \\
\text { c }\end{array}$ & 39,3 \\
\hline 22 & 215 & 0.2 & 60 & 100 & 40 & 90 & 80 & Octet & 40,4 \\
\hline 23 & 215 & 0.2 & 60 & 100 & 40 & 90 & 80 & Cross & 31 \\
\hline 24 & 215 & 0.2 & 60 & 100 & 40 & 90 & 80 & Cross 3D & 33,2 \\
\hline 25 & 215 & 0.2 & 60 & 100 & 40 & 90 & 80 & Gyroid & 39,8 \\
\hline 26 & 215 & 0.2 & 60 & 100 & 40 & 90 & 80 & Zig Zag & 41,9 \\
\hline 27 & 225 & 0.2 & 60 & 100 & 40 & 90 & 80 & Triangles & 34,9 \\
\hline 28 & 225 & 0.2 & 60 & 100 & 40 & 90 & 80 & Lines & 39,4 \\
\hline 29 & 225 & 0.2 & 60 & 100 & 40 & 90 & 80 & Grid & 37 \\
\hline 40 & 225 & 0.2 & 60 & 100 & 40 & 90 & 80 & $\begin{array}{c}\text { Tri } \\
\text { Hexagon }\end{array}$ & 37,1 \\
\hline 31 & 225 & 0.2 & 60 & 100 & 40 & 90 & 80 & Cubic & 39,9 \\
\hline 32 & 225 & 0.2 & 60 & 100 & 40 & 90 & 80 & $\begin{array}{c}\text { Cubic } \\
\text { Subdivisio } \\
\mathrm{n}\end{array}$ & 36,9 \\
\hline 33 & 225 & 0.2 & 60 & 100 & 40 & 90 & 80 & $\begin{array}{l}\text { Quarter } \\
\text { Cubic }\end{array}$ & 41,5 \\
\hline
\end{tabular}


Pengaruh Parameter Proses Terhadap Kekuatan Tarik Produk 3d Printing Menggunakan Filamen Polylactic Acid (PLA) Buatan R3d Maker

\begin{tabular}{cccccccccc}
\hline $\begin{array}{c}\text { Exp. } \\
\text { No }\end{array}$ & $\begin{array}{c}\text { Nozzle } \\
\text { Temper } \\
\text { ature } \\
\left({ }^{\circ} \boldsymbol{C}\right)\end{array}$ & $\begin{array}{c}\text { Layer } \\
\text { thickn } \\
\text { ess } \\
(\mathbf{m m})\end{array}$ & $\begin{array}{c}\text { Bed } \\
\text { temperatu } \\
\boldsymbol{r e}\left({ }^{\circ} \boldsymbol{C}\right)\end{array}$ & $\begin{array}{c}\text { Travel } \\
\text { Speed } \\
(\mathbf{m m} / \mathbf{s})\end{array}$ & $\begin{array}{c}\text { Printing } \\
\text { Speed } \\
(\mathbf{m m} / \mathbf{s})\end{array}$ & $\begin{array}{c}\text { Orientasi } \\
\text { vertikal } \\
\left({ }^{\circ}\right)\end{array}$ & $\begin{array}{c}\text { Infill } \\
\text { densi } \\
\text { ty } \\
(\%)\end{array}$ & $\begin{array}{c}\text { Infill } \\
\text { patern }\end{array}$ & $\begin{array}{c}\text { Nilai } \\
\text { Kakuatan } \\
\text { Tarik } \\
(\mathbf{M P a})\end{array}$ \\
\hline 34 & 225 & 0.2 & 60 & 100 & 40 & 90 & 80 & $\begin{array}{c}\text { Concentri } \\
\text { c }\end{array}$ & 37 \\
\hline 35 & 225 & 0.2 & 60 & 100 & 40 & 90 & 80 & Octet & 39,5 \\
\hline 36 & 225 & 0.2 & 60 & 100 & 40 & 90 & 80 & Cross & 34,8 \\
\hline 37 & 225 & 0.2 & 60 & 100 & 40 & 90 & 80 & Cross 3D & 37,8 \\
\hline 39 & 225 & 0.2 & 60 & 100 & 40 & 90 & 80 & Gyroid & 35,4 \\
\hline
\end{tabular}

Dari tabel 2 diperoleh data yang menunjukkan bahwa variasi parameter yang digunakan akan mempengaruhi nilai kekuatan tarik dari setiap spesimen uji di mana data tersebut menunjukkan hasil yang berbeda-beda. Jika data ini dibandingkan dengan penelitian sebelumnya yang telah dilakukan oleh (Suzen, 2020) dengan orientasi pencetakan yang berbeda maka terlihat bahwa orientasi pencetakan akan berpengaruh terhadap nilai kekuatan tarik produk 3D printing. Pada penelitian yang dilakukan oleh (Suzen, 2020) nilai kekuatan tarik tertinggi di dapatkan pada spesimen uji yang menggunakan infill pattern dengan tipe concentric dan nozzle temperature $215^{\circ} \mathrm{C}$. Sedangkan, pada penelitian ini nilai kekuatan tarik tertinggi di dapatkan pada spesimen uji yang menggunakan infill pattern dengan tipe zig zag dan nozzle temperature $205^{\circ} \mathrm{C}$.

\section{Analisa Hasil Pengujian Tarik}

Berdasarkan data yang diperoleh dari hasil pengujian tarik yang terdapat pada tabel 2, maka di buatlah sebuah grafik hasil pengujian tarik untuk mengetahui perbedaan kekuatan tarik pada setiap parameter proses yang digunakan. Perbedaan kekuatan tarik ini menyebabkan adanya nilai kekuatan tarik tertinggi dan terendah. Grafik hasil pengujian tarik dapat dilihat pada Gambar 4. 


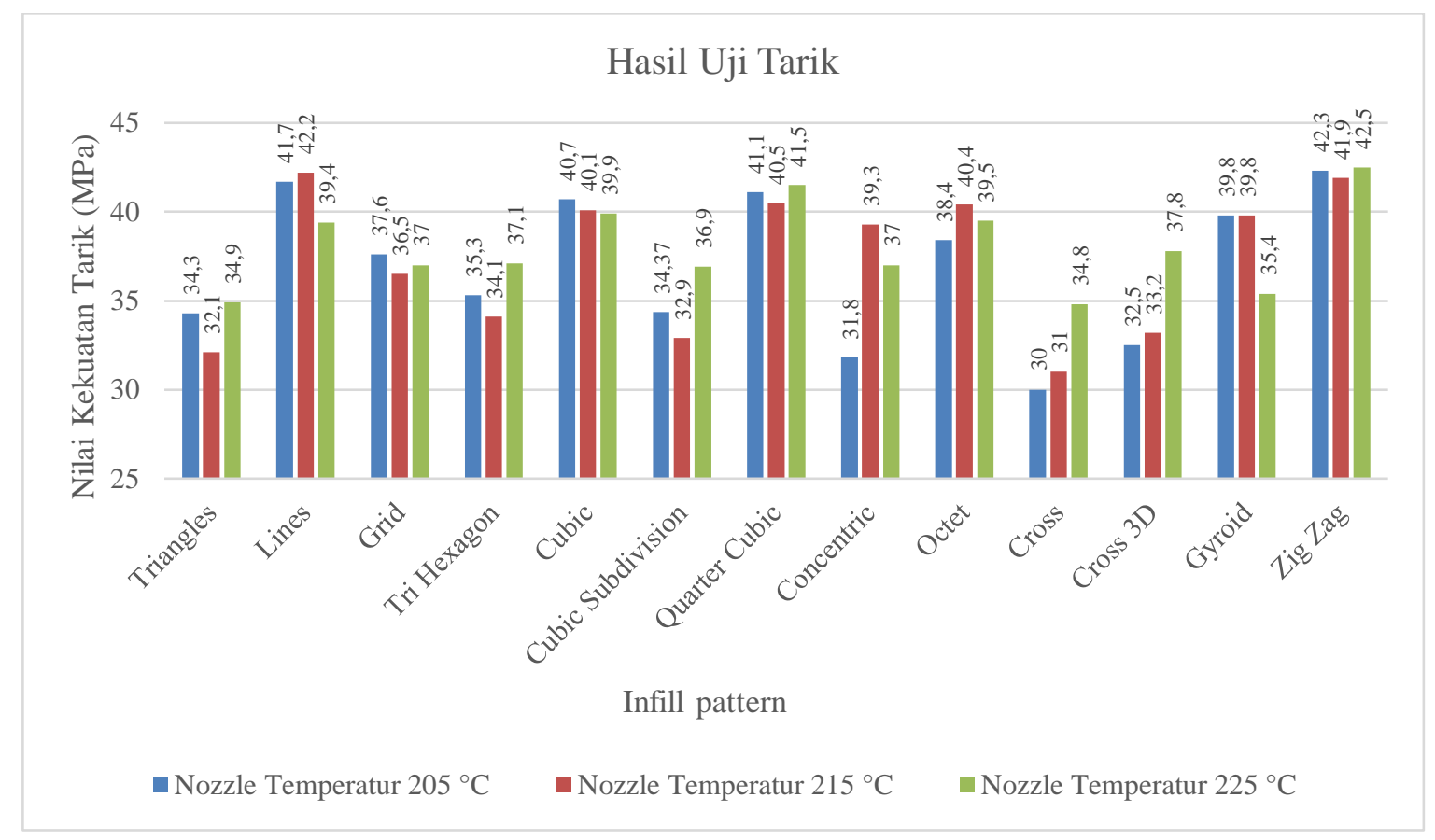

\section{Gambar 4 Grafik Hasil Pengujian Tarik}

Dari grafik yang ditunjukkan pada Gambar 4 dapat diketahui bahwa terdapat perbedaan nilai kekuatan tarik dari tipe infill pattern yang digunakan terhadap masingmasing varians dari nozzle temperature. Pada varian level $205^{\circ} \mathrm{C}$ nilai kekuatan tarik tertinggi berada pada infill pattern dengan tipe zig zag sebesar 42,3 MPa, sedangkan nilai kekuatan tarik terendah sebesar $30 \mathrm{MPa}$ yang menggunakan infill pattern dengan tipe cross. Akan tetapi pada varian level $215^{\circ} \mathrm{C}$ nilai kekuatan tarik terendah menggunakan tipe infill patern yang berbeda dengan varians level $205^{\circ} \mathrm{C}$ dimana tipe dari infill pattern yang digunakan yaitu cross dan untuk tipe infill patern yang memiliki nilai kekuatan tarik tertinggi menggunkan tipe infill pattern lines dengan nilai kekuatan tarik secara berurutan sebesar $31 \mathrm{MPa}$ dan 42,2 MPa. Sedangkan pada varian level $225^{\circ} \mathrm{C}$ nilai kekuatan tarik terendah menggunakan tipe infill pattern dengan tipe triangle dan untuk nilai kekuatan tarik tertinggi menggunakan tipe infill pattern yang sama dengan varian level $205^{\circ} \mathrm{C}$ dengan nilai kekuatan tariknya secara berurutan sebesar 34,9 MPa dan 42,5 MPa.

Pada infill pattern dengan tipe triangle, quarter cubic, tri hexagon, cubic subdivision dan zig zag nilai kekuatan tarik tertinggi berada pada nozzle temperature $225^{\circ} \mathrm{C}$ dan nilai kekuatan tarik terendah berada pada nozzle temperature $215^{\circ} \mathrm{C}$. Sedangkan infill pattern dengan tipe line akan menghasilkan nilai kekuatan tarik terendah pada nozzle temperature $225^{\circ} \mathrm{C}$ dan nilai kekuatan tarik tertinggi berada pada nozzle temperature $215^{\circ} \mathrm{C}$. Pada infill pattern dengan tipe octet dan concentric nozzle temperature $215^{\circ} \mathrm{C}$ akan menghasilkan nilai kekuatan tarik tertinggi dan nilai kekuatan tarik terendah di dapatkan pada saat menggunakan nozzle temperature $205^{\circ} \mathrm{C}$. Sedangkan nozzle temperature $215^{\circ} \mathrm{C}$ akan menghasilkan nilai kekuatan tarik terendah dan nozzle temperature $215^{\circ} \mathrm{C}$ akan menghasilkan nilai kekuatan tarik tertinggi pada infill pattern dengan tipe grid. Infill pattern dengan tipe cross dan cross $3 d$ akan menghasilkan nilai 
kekuatan tarik tertinggi pada nozzle temperature $225^{\circ} \mathrm{C}$ dan nilai kekuatan tarik terendah akan dihasilkan oleh nozzle temperature $205^{\circ} \mathrm{C}$. Sedangkan nozzle temperature $225^{\circ} \mathrm{C}$ akan menghasilkan nilai kekuatan tarik terendah dan nilai kekuatan tarik terendah akan dihasilkan oleh nozzle temperature $205^{\circ} \mathrm{C}$ pada infill pattern dengan tipe cubic. Pada infill pattern dengan tipe gyroid nilai kekuatan tarik tertinggi dihasilkan pada nozzle temperature $205^{\circ} \mathrm{C}$ dan $215^{\circ} \mathrm{C}$, dan nilai kekuatan tarik terendah dihasilkan pada nozzle temperature $225^{\circ} \mathrm{C}$.

Hal ini menunjukan bahwa infill pattern dan nozzle temperature memiliki pengaruh terhadap hasil dari pengujian tarik dengan nilai kekuatan tarik tertinggi sebesar 42,5 MPa yang menggunakan infill pattern dengan tipe zig zag dan nozzle temperature sebesar $225^{\circ} \mathrm{C}$. sedangkan nilai kekuatan tarik terendah sebesar $30 \mathrm{MPa}$ yang menggunakan infill pattern dengan tipe cross.

\section{Kesimpulan}

Berdasarkan hasil pengolahan data yang telah dilakukan, maka dapat disimpulkan bahwa perbedaan tipe infill pattern dan perbedaaan nozzle temperature yang digunakan akan memiliki pengaruh terhadap kekuatan tarik produk 3D printing dengan orientasi sudut pencetakan vertikal sebesar $90^{\circ}$ menggunakan filamen polylacticacid (PLA) dengan nilai kekuatan tarik tertinggi yang terdapat pada penelitian ini sebesar 42,5 $\mathrm{MPa}$ yang menggunakan infill pattern dengan tipe zig zag dan nozzle temperature sebesar $205^{\circ} \mathrm{C}$. Sedangkan, nilai kekuatan tarik terendah sebesar $30 \mathrm{MPa}$ yang menggunakan infill pattern dengan tipe cross. 
Rikky Ardiansyah, Zaldy Sirwansyah Suzen, Erwansyah

\section{Bibliografi}

Arif, Muhammad. (2016). Bahan Ajar Rancangan Teknik Industri. Deepublish.

Budiman, Wesley, Anggono, Juliana, \& Tanoto, Yopi. (2016). Pengaruh Orientas Obyek Hasil Fused Deposition Modeling pada Waktu Proses. Jurnal Teknik Mesin, 16(2), 41-46.

Grabowik, Cezary, Kalinowski, Krzysztof, Ćwikła, Grzegorz, Paprocka, Iwona, \& Kogut, Pawel. (2017). Tensile tests of specimens made of selected group of the filament materials manufactured with FDM method. MATEC Web of Conferences, 112, 4017. EDP Sciences. https://doi.org/10.1051/matecconf/201711204017.

Izdebska-Podsiadły, Joanna, \& Thomas, Sabu. (2015). Printing on polymers: fundamentals and applications. William Andrew.

Mohamed, Omar A., Masood, Syed H., \& Bhowmik, Jahar L. (2015). Optimization of fused deposition modeling process parameters: a review of current research and future prospects. Advances in Manufacturing, 3(1), 42-53. https://doi.org/10.1007/s40436-014-0097-7.

Nugroho, Aris Widyo, \& Budiantoro, Cahyo. (2019). Improving the tensile properties of 3D printed PLA by optimizing the processing parameter. JEMMME (Journal of Energy, Mechanical, Material, and Manufacturing Engineering), 4(1), 29-36. https://doi.org/10.22219/jemmme.v6i2.

Riza, Eduar Iqbal, Budiyantoro, Cahyo, \& Nugroho, Aris Widyo. (2020). PENINGKATAN KEKUATAN LENTUR PRODUK 3D PRINTING BERBAHAN PETG DENGAN OPTIMASI PARAMETER PROSES MENGGUNAKAN METODE TAGUCHI. Media Mesin: Majalah Teknik Mesin, 21(2), 66-75. https://doi.org/10.23917/mesin.v21i2.10856.

Sulistiyanto, Dwi. (2017). Analisis parameter injection moulding terhadap waktu siklus tutup botol $500 \mathrm{ml}$ menggunakan desain box-behnken.

Suzen, Z. S. (2020). Pengaruh Tipe Infill dan Temperatur Nozzle terhadap Kekuatan Tarik Produk 3D Printing Filamen Pla+ Esun. Manutech: Jurnal Teknologi Manufaktur, 12(02), 73-80. https://doi.org/10.33504/manutech.v12i2.133.

Yao, Tianyun, Deng, Zichen, Zhang, Kai, \& Li, Shiman. (2019). A method to predict the ultimate tensile strength of 3D printing polylactic acid (PLA) materials with different printing orientations. Composites Part B: Engineering, 163, 393-402. https://doi.org/10.1016/j.compositesb.2019.01.025. 